\section{Pruning and Training Affect Yield but Not Machine Harvest Efficiency of 'Meeker' Red Raspberry}

\author{
Bernadine C. Strik ${ }^{\mathbf{1}}$ and Helen K. Cahn ${ }^{2}$ \\ Department of Horticulture, Oregon State University, 4017 ALS, Corvallis, \\ OR 97331-7304
}

Additional index words. Rubus idaeus, hill system, stool system, hedgerow, topping, arc cane training, looping, cane density, fruit weight, harvest losses

\begin{abstract}
Meeker' red raspberry (Rubus idaeus L.) cane densities of 5, 10, or 15 canes/hill in a hill system, with canes topped at $2 \mathrm{~m}$ or the entire cane length retained and looped, were compared with a 15- or 30-cm-wide hedgerow with canes topped at $2 \mathrm{~m}$ from 1995 to 1997. Cane density among all treatments ranged from 2.2 to 9.9 canes $/ \mathrm{m}^{2}$ during the study. Plots were harvested by machine every 2 days. Within the hill system, total yield increased with cane density in all years. Looped treatments produced a higher yield/plot than did topped ones in all years except 1996, when the yield difference was insignificant because looped canes had greater winter injury. Weight per fruit ranged from 5.4\% to $9.7 \%$ less on looped than on topped canes. Hedgerow systems had a lower yield than hill systems in 1996, but a higher yield in 1997. Losses due to machine harvest were not affected by pruning (cane density or topping) or production system (hill system or hedgerow) and averaged $16.2 \%$ of total yield in 1997. Thirty-five percent of the loss due to machine harvest occurred between harvests.
\end{abstract}

Over $80 \%$ of the 4765 ha of red raspberries grown in the Pacific Northwest (Oregon and Washington) were machine harvested in 1997. With increased costs and shortages of available labor, the percentage of the crop that is machine harvested is expected to increase.

Over the last 20 years, machine harvester manufacturers have improved their equipment, improving efficiency of harvest by decreasing the percentage of fruit loss on the ground. Manufacturers, however, feel that the cultural systems currently in practice could be modified to reduce losses (Littau Harvesters, Inc., and Korvan, Inc., personal communication).

Various types of self-propelled, over-therow machines are used. The rotary shaker machine is becoming more common than the horizontal "slapper" or "sway" types. Fruit are dislodged from the plants by vibrating rods that pass along both sides of the row and transmit the shaking action through the plant. Detached fruit drop to spring-loaded, overlapping catch plates, then roll onto pocket belt conveyors that move the fruit through a pneumatic cleaner onto an inspection belt and into

Received for publication 8 June 1998. Accepted for publication 16 Nov. 1998. Oregon State Univ. Agricultural Experiment Station technical paper no. 11443. The authors thank the Oregon Raspberry and Blackberry Commission, Littau Harvesters, Inc., and the Washington Red Raspberry Commission for supporting this research. The cost of publishing this paper was defrayed in part by the payment of page charges. Under postal regulations, this paper therefore must be hereby marked advertisement solely to indicate this fact.

${ }^{1}$ Professor; e-mail: Strikb@bcc.orst.edu

${ }^{2}$ Research Assistant, North Willamette Research and Extension Center. containers. Machine-harvested fruit have higher percent soluble solids, lower acidity, and superior color than do hand-harvested fruit (Morris, 1983).

Cormack and Waister (1976) reported 25\% losses in mechanically harvested berries grown in hedgerows in Scotland. Kingston and O'Donoghue (1987) found $24 \%$ loss of machine-harvested fruit in 'Skeena' raspberry grown in hedgerows in New Zealand. Simpson et al. (1987), when testing three different machines in five commercial fields in Washington State, reported losses of $21 \%$ in the hill system (stools). Martin and Nelson (1987) reported a loss of $22 \%$ in 'Meeker' grown in a hill system using a "slapper" machine.

Loss of machine-harvested fruit is affected by the operator, who controls machine speed, beater speed, and centering of the machine on the row, as well as by the type of machine and cultural practices. Hedgerow plantings, where the catcher plates remain open at a constant distance and fit tightly against the canes, may reduce fruit loss to the ground in comparison with hill systems; however, this has not been studied.

Essentially all red raspberries in the Pacific Northwest are produced in a hill system. Plants are set 60 to $75 \mathrm{~cm}$ apart in rows spaced $3 \mathrm{~m}$ (center-to-center) to accommodate machine harvesters. Growers often thin out canes in the hills at pruning time. They train the canes on the trellis either as a bundle with the canes topped at $\approx 2 \mathrm{~m}$, or as looped bundles with the canes either slightly topped or their entire length retained.

Yield of a raspberry cane is determined by cane diameter, cane length, number of nodes, number of nodes with a fruiting lateral, number of fruit per lateral, and fruit weight. Yield per unit area is also determined by the number of canes per unit area (Dale, 1989).

Mason(1981), in Scotland, found that cane density was greater in a hedgerow than in a hill system. However, the hedgerow had a greater yield than the hill system in only 2 of 5 years when both systems were topped at $1.5 \mathrm{~m}$. In the hill system, weight per fruit tended to be greater, with more fruit per lateral (Mason, 1981).

The minimum cane density required to give a maximum yield has differed in previous research studies. In North America, Buszard (1986) studied cane densities as high as 10 canes $/ \mathrm{m}^{2}$ for three cultivars grown in a hedgerow, and obtained maximum yield with $\approx 3.3$ canes $/ \mathrm{m}^{2}$. In a hill system, yields were highest at the highest cane densities imposed, 5.3 canes $/ \mathrm{m}^{2}$ (Crandall et al., 1974) and 6.4 canes $/ \mathrm{m}^{2}$ (Martin and Nelson, 1987). Below these values, yield is often proportional to cane number (Crandall et al., 1974). Maximum yield and cane density relationships for red raspberries grown in hedgerows in Europe have been similar (e.g., Wood et al., 1961). Yield per cane increased with planting distance, but yield per hectare was reduced if either the minimum cane density was not reached or the increased yield per cane was not sufficient to compensate for the wider planting distances.

In many production regions, the fruiting cane is topped to either remove weak or dead sections or to make the cane more manageable for hand harvest. Untopped canes, or those left longer than the conventional length, generally produced greater yields than those topped normally (Crandall et al., 1974; Wood et al., 1961). However, Martin and Nelson (1987) found no effect of training system (topped compared to retaining the entire cane) on machine-harvested yield of 'Meeker'. Average fruit size was smaller on untopped than on topped canes (Crandall et al., 1974; Martin and Nelson, 1987) because more, smaller fruit were harvested from the tips of canes (Braun and Garth, 1984). Many growers in the Pacific Northwest top canes to increase fruit size; the gain in fruit size and loss in yield with this practice has not been well documented. Also, the reduction in size may not be important for machine-harvested fruit for processing.

The objectives of our study were to determine the effects of: 1) hill vs. hedgerow systems at various cane densities; and 2) training and pruning within the hill system on total yield, fruit weight, and machine harvest efficiency.

\section{Materials and Methods}

In Spring 1993, a field trial of 'Meeker' summer-bearing red raspberry was established at the North Willamette Research and Extension Center, Aurora, Ore., on a quatama soil (fine-loamy, mixed, mesic Aquultic Haploxeralfs).

The experiment consisted of eight treatments and with four replicates, arranged in a completely randomized design. The treatments were: a hill system with canes topped at $2 \mathrm{~m}$ 
Table 1. Analysis of variance results for training and cane density effects within hill system treatments on yield and its components of 'Meeker' red raspberry, 1995-97.

\begin{tabular}{|c|c|c|c|c|c|c|c|c|c|}
\hline \multirow[b]{3}{*}{ Variable } & \multicolumn{9}{|c|}{ Year } \\
\hline & \multicolumn{3}{|c|}{1995} & \multicolumn{3}{|c|}{1996} & \multicolumn{3}{|c|}{1997} \\
\hline & $\mathrm{T}^{\mathrm{z}}$ & $\mathrm{D}^{\mathrm{y}}$ & $\mathrm{T} \times \mathrm{D}$ & $\mathrm{T}$ & $\mathrm{D}$ & $\mathrm{T} \times \mathrm{D}$ & $\mathrm{T}$ & $\mathrm{D}$ & $\mathrm{T} \times \mathrm{D}$ \\
\hline Marketable yield & $*$ & $* * *$ & NS & NS & **** & NS & $* *$ & $* * *$ & NS \\
\hline Total yield & $*$ & $* * *$ & NS & NS & *** & NS & $* *$ & $* * *$ & NS \\
\hline Yield/cane & NS & $* *$ & NS & NS & $* * *$ & NS & $* *$ & $* * *$ & NS \\
\hline Fruit weight & $* *$ & NS & NS & $* *$ & $* *$ & NS & $* *$ & NS & NS \\
\hline Percent culls & NS & $* *$ & NS & NS & NS & NS & NS & NS & NS \\
\hline Percent drops & NS & NS & NS & NS & NS & NS & NS & NS & NS \\
\hline Percent budbreak & NS & $* *$ & NS & $* * *$ & $*$ & NS & $* * *$ & NS & $*$ \\
\hline
\end{tabular}

${ }^{2} \mathrm{~T}=$ training; bundles topped at $2 \mathrm{~m}$ or entire cane length retained and arc-cane trained (looped).

${ }^{\mathrm{y}} \mathrm{D}=$ cane density at 5,10 , or 15 canes per hill.

Ns, *,******N Nonsignificant or significant at $P \leq 0.05,0.01$, or 0.001 , respectively.

with target cane densities of either 5,10 , or 15 canes per hill $\left(2.2,4.4\right.$, or 6.6 canes $\left./ \mathrm{m}^{2}\right)$; a hill system with the entire cane length retained and loop-trained at 5,10 , or 15 canes/hill; and a hedgerow with canes topped at $2 \mathrm{~m}$ and confined to either a $15-\mathrm{cm}$ (densities ranged from 3.3 to 7.7 canes $/ \mathrm{m}^{2}, 1995-97$ ) or 30-cm width (from 4.4 to 9.9 canes $/ \mathrm{m}^{2}$ ). The hill systems were established with nursery plants (short floricane with attached roots) set $75 \mathrm{~cm}$ apart in the row. The hedgerows were established with root cuttings (to encourage better formation of a hedgerow) at a spacing of $60 \mathrm{~cm}$ in the row. Row spacing was $3 \mathrm{~m}$ from center-tocenter to accommodate machine harvest.

Each plot was $6 \mathrm{~m}$ in length, and plots were separated by a $3-\mathrm{m}$ section without plants so that the machine could be stopped and "cleared" of all fruit before moving to the next plot. From 1995 to 1997, fruit were harvested by a Littau machine (Littau Harvesters Inc., Stayton,
Ore.) equipped with a two-head, freewheeling, rotary shaker. In 1995 and 1996, fruit were harvested by machine every $5 \mathrm{~d}$. Yield loss was evaluated by collecting and weighing fruit left on the ground from a 1.2-m section of row in each plot. In 1997, machine harvest was every 2 to $3 \mathrm{~d}$. Harvest efficiency was evaluated by weighing fruit collected just before harvesting began (loss between harvests) and those collected right after harvest (during harvest loss). Twenty-five fruit were collected at each harvest and a weighted average calculated. Cull weight was considered nonmarketable fruit (rotten and green fruit).

Postharvest yield component data were collected from five canes in each plot. (Fruit number per lateral was subsampled from one apical, middle, and basal lateral on each cane.) Cane diameter was measured at a 30-cm height. Primocane number per plot was counted after fruit harvest (before pruning and training) and floricane number in March of each year.

Data were analyzed by analysis of variance for the independent factors of year, training (looped or topped), and cane density, with mean separations by protected least significant difference. In a full analysis of treatment effects, a contrast was used to compare the hedgerows with the hill systems for yield and other components. Yield and yield/cane were regressed on cane density calculated for all treatments in each year (SAS, 1988).

\section{Results and Discussion}

Year had a significant effect on all variables measured. Within the hill systems, cane density (canes/hill) had a significant effect on yield per plot and yield/cane in all 3 years, fruit weight in 1996, percentage of culls in 1995, and percentage of budbreak in 1995 and 1996 (Table 1). Training (topped or entire cane looped) had a significant effect on yield per plot in 1995 and 1997, yield/cane in 1997, fruit weight from 1995 to 1997, and percent budbreak in 1996 and 1997. There were no training $\times$ cane density interactions, except for percentage of budbreak in 1997 (Table 1).

Hill systems, vegetative effects. Budbreak was significantly higher at the lower cane densities in 1995 and 1996 (Table 2). Percentage of budbreak was lower on the looped cane treatments, where cane length was longer (Table 2).

Cane diameter was not affected by cane density or training system (data not shown). There was no effect of training system on fruit number per lateral in 1995 or 1996 . However,

Table 2. Effects of cane density and pruning/training on yield and its components of 'Meeker' red raspberry, 1995-97.

\begin{tabular}{|c|c|c|c|c|c|c|c|c|}
\hline \multicolumn{2}{|c|}{ Treatment $^{\mathbf{z}}$} & \multirow[b]{2}{*}{$\begin{array}{c}\text { Total yield } \\
\text { (kg/plot) }\end{array}$} & \multirow[b]{2}{*}{ Nodes/cane } & \multirow[b]{2}{*}{$\begin{array}{c}\text { Internode } \\
\text { length }(\mathrm{cm})\end{array}$} & \multirow[b]{2}{*}{$\begin{array}{c}\text { Budbreak } \\
(\%)\end{array}$} & \multirow[b]{2}{*}{$\begin{array}{l}\text { Average no. } \\
\text { fruit/lateral }\end{array}$} & \multirow[b]{2}{*}{$\begin{array}{c}\text { Cull } \\
(\% \text { harvested } \\
\text { yield })\end{array}$} & \multirow[b]{2}{*}{$\begin{array}{l}\text { Drop } \\
\text { (\% total } \\
\text { yield) } \\
\end{array}$} \\
\hline Training & $\begin{array}{c}\text { Canes/hill } \\
\text { or width } \\
(\mathrm{cm})\end{array}$ & & & & & & & \\
\hline & & & & 1995 & & & & \\
\hline $\mathrm{T}$ & 5 & $13.8 \mathrm{~d}^{\mathrm{y}}$ & $38.9 \mathrm{~b}$ & $4.8 \mathrm{a}$ & $49.6 \mathrm{ab}$ & 13.2 & 12.6 & 7.1 \\
\hline $\mathrm{T}$ & 10 & $16.6 \mathrm{~b}-\mathrm{d}$ & $37.8 \mathrm{~b}$ & $4.6 \mathrm{ab}$ & $39.2 \mathrm{c}$ & 10.5 & 10.4 & 8.2 \\
\hline $\mathrm{T}$ & 15 & $17.8 \mathrm{a}-\mathrm{c}$ & $42.3 \mathrm{~b}$ & $4.5 \mathrm{ab}$ & $34.7 \mathrm{c}$ & 9.0 & 9.8 & 8.6 \\
\hline $\mathrm{L}$ & 5 & $14.3 \mathrm{~cd}$ & $64.3 \mathrm{a}$ & $4.1 \mathrm{bc}$ & $50.9 \mathrm{a}$ & 9.1 & 11.8 & 8.9 \\
\hline $\mathrm{L}$ & 10 & $21.5 \mathrm{a}$ & $60.1 \mathrm{a}$ & $3.8 \mathrm{c}$ & $37.1 \mathrm{c}$ & 9.4 & 8.4 & 7.9 \\
\hline $\mathrm{L}$ & 15 & $18.6 \mathrm{ab}$ & $63.3 \mathrm{a}$ & $3.8 \mathrm{c}$ & $42.1 \mathrm{a}-\mathrm{c}$ & 9.1 & 10.5 & 7.1 \\
\hline HR & $15 \mathrm{~cm}$ & $16.4 \mathrm{~cd}$ & $38.0 \mathrm{~b}$ & $4.8 \mathrm{a}$ & $48.8 \mathrm{ab}$ & 12.4 & 9.4 & 9.4 \\
\hline \multirow[t]{2}{*}{ HR } & $30 \mathrm{~cm}$ & $18.2 \mathrm{ab}$ & $39.9 \mathrm{~b}$ & $4.5 \mathrm{ab}$ & $41.2 \mathrm{bc}$ & 11.9 & 9.1 & 9.1 \\
\hline & & & & 1996 & & & & \\
\hline $\mathrm{T}$ & 5 & $17.9 \mathrm{bd}$ & $29.1 \mathrm{~b}$ & $6.3 \mathrm{ab}$ & $61.1 \mathrm{a}$ & 16.6 & 10.0 & 31.1 \\
\hline $\mathrm{T}$ & 10 & $20.8 \mathrm{ab}$ & $28.2 \mathrm{~b}$ & $6.3 \mathrm{ab}$ & $49.9 \mathrm{bc}$ & 15.3 & 9.0 & 25.5 \\
\hline $\mathrm{T}$ & 15 & $23.0 \mathrm{a}$ & $27.6 \mathrm{~b}$ & $6.4 \mathrm{ab}$ & $54.6 \mathrm{ab}$ & 16.2 & 7.9 & 28.9 \\
\hline $\mathrm{L}$ & 5 & $17.7 \mathrm{~b}-\mathrm{d}$ & $60.1 \mathrm{a}$ & $5.2 \mathrm{~d}$ & $42.7 \mathrm{~cd}$ & 15.0 & 9.2 & 28.4 \\
\hline $\mathrm{L}$ & 10 & $23.9 \mathrm{a}$ & $55.4 \mathrm{a}$ & $5.6 \mathrm{~cd}$ & $40.3 \mathrm{~d}$ & 16.2 & 6.8 & 26.5 \\
\hline $\mathrm{L}$ & 15 & $23.5 \mathrm{a}$ & $56.4 \mathrm{a}$ & $5.7 \mathrm{~b}-\mathrm{d}$ & $31.0 \mathrm{e}$ & 12.6 & 7.5 & 30.2 \\
\hline HR & $15 \mathrm{~cm}$ & $15.2 \mathrm{~cd}$ & $26.2 \mathrm{~b}$ & $6.9 \mathrm{a}$ & $47.8 \mathrm{~b}-\mathrm{d}$ & 13.5 & 10.4 & 35.2 \\
\hline \multirow[t]{2}{*}{ HR } & $30 \mathrm{~cm}$ & $13.9 \mathrm{c}$ & $28.1 \mathrm{~b}$ & $6.2 \mathrm{a}-\mathrm{c}$ & $45.9 \mathrm{~b}-\mathrm{d}$ & 10.5 & 8.8 & 29.9 \\
\hline & & & & 1997 & & & & \\
\hline $\mathrm{T}$ & 5 & $19.4 \mathrm{~d}$ & $23.2 \mathrm{c}$ & $7.9 \mathrm{~b}$ & $67.0 \mathrm{a}$ & $14.7 \mathrm{a}-\mathrm{c}$ & $4.2 \mathrm{a}$ & 17.9 \\
\hline $\mathrm{T}$ & 10 & $20.7 \mathrm{~cd}$ & $22.5 \mathrm{c}$ & $8.1 \mathrm{ab}$ & $57.6 \mathrm{ab}$ & $16.1 \mathrm{ab}$ & $3.9 \mathrm{ab}$ & 13.1 \\
\hline $\mathrm{T}$ & 15 & $24.7 \mathrm{bc}$ & $19.3 \mathrm{c}$ & $9.2 \mathrm{a}$ & $58.8 \mathrm{ab}$ & $16.8 \mathrm{a}$ & $3.4 \mathrm{~b}-\mathrm{d}$ & 16.6 \\
\hline $\mathrm{L}$ & 5 & $20.4 \mathrm{~cd}$ & $59.8 \mathrm{a}$ & $5.5 \mathrm{~d}$ & $46.1 \mathrm{~cd}$ & $12.2 \mathrm{~cd}$ & $4.0 \mathrm{ab}$ & 16.4 \\
\hline $\mathrm{L}$ & 10 & $26.6 \mathrm{ab}$ & $52.8 \mathrm{~b}$ & $6.3 \mathrm{~cd}$ & $52.9 \mathrm{bc}$ & $12.2 \mathrm{~cd}$ & $3.5 \mathrm{a}-\mathrm{d}$ & 18.2 \\
\hline $\mathrm{L}$ & 15 & $30.8 \mathrm{a}$ & $57.8 \mathrm{ab}$ & $5.4 \mathrm{~d}$ & $40.7 \mathrm{~d}$ & $11.3 \mathrm{~cd}$ & $3.7 \mathrm{a}-\mathrm{c}$ & 16.9 \\
\hline HR & $15 \mathrm{~cm}$ & $29.7 \mathrm{a}$ & $22.8 \mathrm{c}$ & $7.9 \mathrm{~b}$ & $51.0 \mathrm{bc}$ & $13.2 \mathrm{~b}-\mathrm{d}$ & $3.1 \mathrm{~cd}$ & 14.9 \\
\hline HR & $30 \mathrm{~cm}$ & $30.8 \mathrm{a}$ & $24.1 \mathrm{c}$ & $7.3 \mathrm{bc}$ & $63.2 \mathrm{a}$ & $11.0 \mathrm{~d}$ & $2.8 \mathrm{~d}$ & 15.8 \\
\hline
\end{tabular}

${ }^{\mathrm{z}} \mathrm{T}=$ Canes topped at $6 \mathrm{ft}$.; $\mathrm{L}=$ canes unpruned and looped; $\mathrm{HR}=$ hedgerow at width indicated.

${ }^{y}$ Mean separation within columns and years by protected LSD, $P \leq 0.05$. 


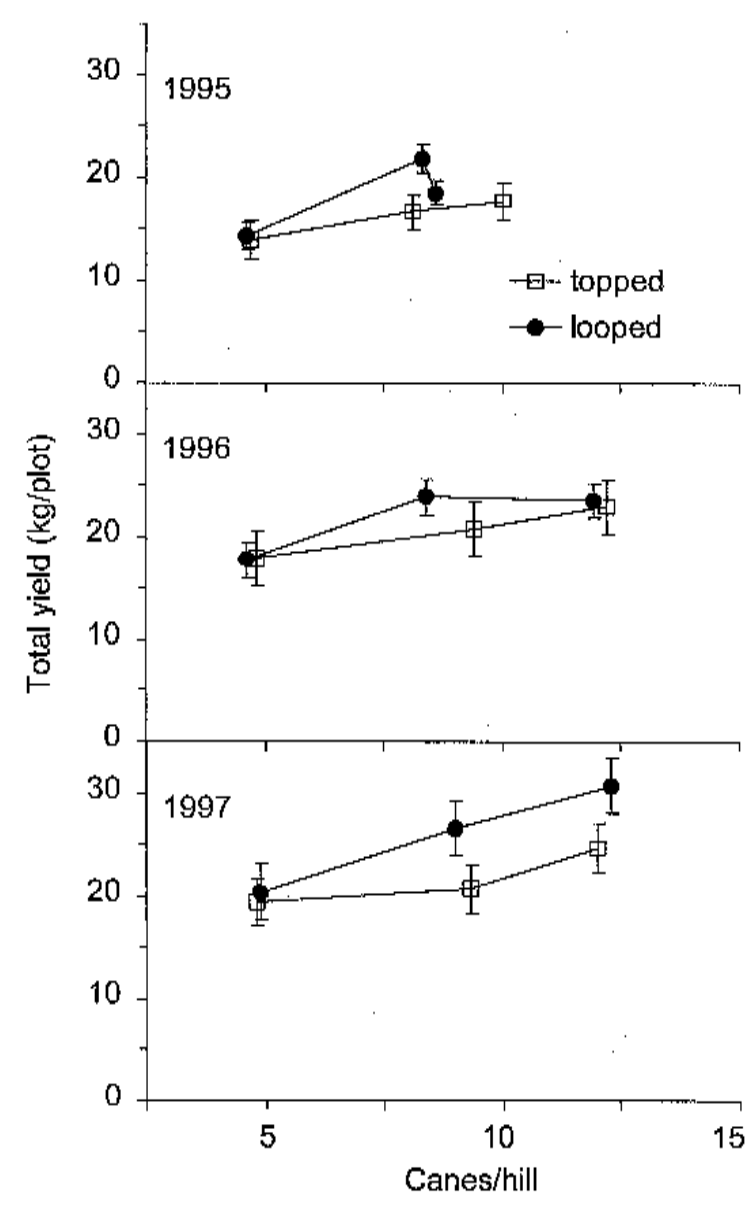

Fig. 1. Effect of the number of canes per hill and topping (at 2-m height) vs. looping (entire cane length) in a hill system on total yield per plot of 'Meeker' red raspberry, 1995-97. Actual cane densities, not target treatment densities, shown.

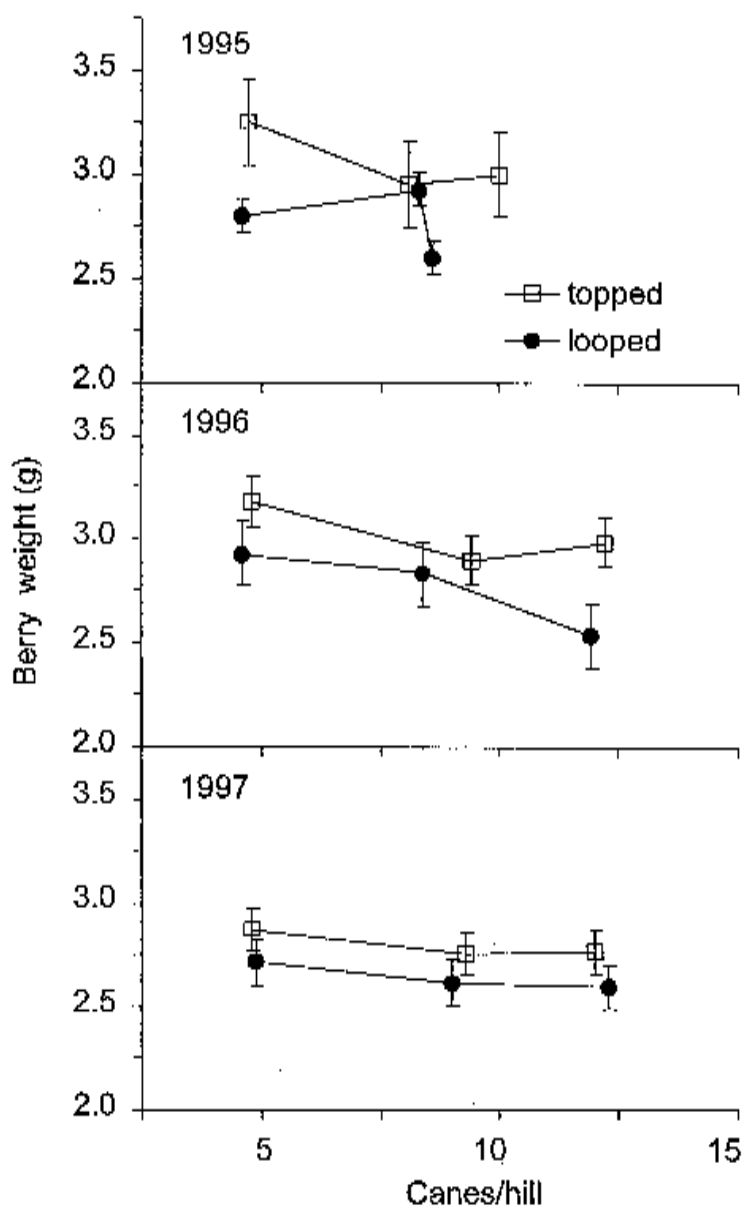

Fig. 2. Effect of the number of canes per hill and topping (at 2-m height) vs. looping (entire cane length) in a hill system on fruit weight of 'Meeker' red raspberry, 1995-97. Actual cane densities, not target treatment densities, shown. in 1997, topped canes had an average of 16 fruit/lateral compared with 12 in looped canes (Table 2).

Hill systems, yield-related effects. Within the hill system, total yield increased with cane density in all years (Fig. 1). In 1995, we had not yet established high cane densities, but in 1997 higher yields might have been possible in the hill system with a cane density $>12$ canes/hill $\left(5.3\right.$ canes $\left./ \mathrm{m}^{2}\right)$. These findings are similar to those of Crandall et al. (1974), who found the greatest yield at the highest cane density imposed (12 canes/hill)

Unlike Martin and Nelson (1987), who found no effect of training system on yield of 'Meeker', we found that looped canes produced significantly higher yields than did topped $(2 \mathrm{~m})$ canes in all years except 1996 (Fig. 1). In 1995 to 1997, length of looped canes averaged $2.4,3.2$, and $3.2 \mathrm{~m}$, respectively. In 1996, looped canes suffered more winter injury than topped canes, a phenomenon that has also been observed in growers' fields after a severe winter. Greater cold damage was evidenced in 1996 by failure of looped canes to yield more than topped ones (data not shown) and the lower percentage of budbreak in looped canes (Table 2). Yield/cane decreased with increased cane density in both training systems (data not shown).
Fruit size was little affected by cane density, as shown by Buszard (1996), but was lower on looped than on topped canes in all years, as reported by Crandall et al. (1974) and Martin and Nelson (1987). Fruit weight on looped canes (average of $2.72 \mathrm{~g}$ per fruit over all years; Fig. 2) was 5.4\% to $9.7 \%$ less than on topped canes in hill systems. However, the increased yield from retaining the entire cane in some years (e.g., 20\% greater yield in 1997, amounting to the equivalent of $2.2 \mathrm{t} \cdot \mathrm{ha}^{-1}$ ) needs to be considered for the processing market and a $5 \%$ to $10 \%(0.14-0.27 \mathrm{~g})$ reduction in fruit weight may not affect quality. Fruit weight was not significantly affected by growing system (hill vs. hedgerow, Table 3) except in 1995, when fruit on hedgerows was smaller (data not shown).

Hedgerows vs. hill systems. Cane densities were higher in hedgerows than in hill systems in all years, but yield of hedgerows did not differ from that of hills in 1995, was significantly lower in 1996, and significantly higher than most hill systems in 1997 (Tables 2 and 3, Fig. 3). Perhaps biennial bearing occurred in the hedgerow treatments, due to greater competition between primocanes and floricanes for light. Also, several years were required for hedgerows to become established. (Cane density increased $>2$-fold within the 15 - and 30 - cm-wide hedgerows in the 3 years of the study.) By 1997, we were better able to train this system to prevent canes from falling from under the training wires, as evidenced by the slow increase in productivity per cane in the hedgerows from 1995 and 1996 to 1997 (data not shown). The 30-cm-wide hedgerow tended to have fewer fruit/lateral than the $15-\mathrm{cm}$-wide hedgerow and the topped hill system treatments (Table 2).

There was a strong positive linear relationship between yield per plot and cane density in

Table 3. Analysis of variance results for the contrast of hedgerow (15 and $30 \mathrm{~cm}$ wide) vs. hill systems $(5,10$, or 15 canes/hill topped at $2 \mathrm{~m}$ or looped) in 'Meeker' red raspberry, 1995-97.

\begin{tabular}{lccc}
\hline \hline & \multicolumn{3}{c}{$\begin{array}{c}\text { Contrast hedgerows } \\
\text { vs. hill systems }\end{array}$} \\
\cline { 2 - 4 } Variable & 1995 & 1996 & 1997 \\
\hline Marketable yield & NS & $* * * /-$ & $* * * /+$ \\
Total yield & NS & $* * * /-$ & $* * * /+$ \\
Fruit weight & $* * /-^{z}$ & NS & NS \\
Percent culls & NS & NS & $* * * /-$ \\
Percent drops & NS & NS & NS
\end{tabular}

${ }^{\mathrm{z}}$ Minus sign (-) indicates hedgerows < hills; plus sign $(+)$ indicates hedgerows $>$ hills.

ns, ${ }^{* *},{ }^{* * *}$ Nonsignificant or significant at $P \leq 0.01$ or 0.001 , respectively. 


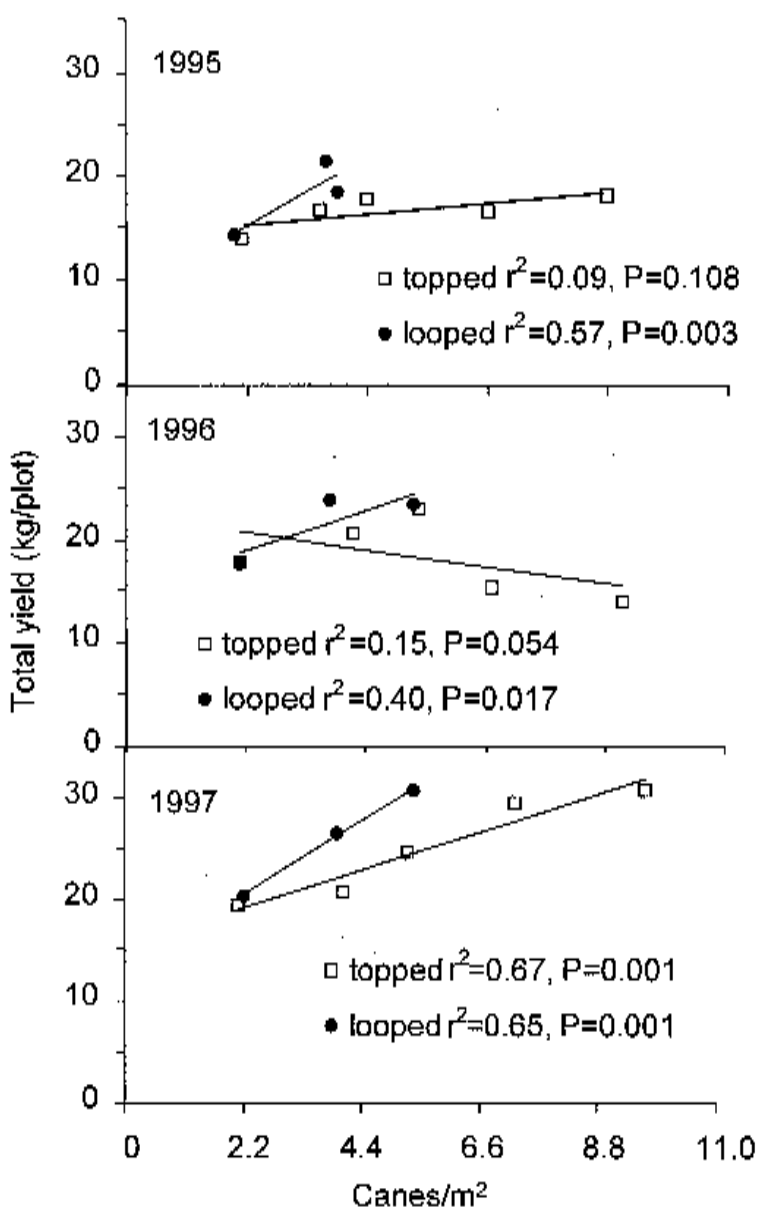

Fig. 3. Effect of cane density and topping (at 2-m height in hill systems and hedgerows) vs. looping (entire cane length in hill systems) on total yield of 'Meeker' red raspberry, 1995-97. Equations for the lines: 1995, topped: $y=0.47 x+14.16$, looped: $y=3.03 x+8.40 ; 1996$, topped: $y=-0.77 x+22.49$, looped: $\mathrm{y}=1.80 \mathrm{x}+14.93 ; 1997$, topped: $\mathrm{y}=1.67 \mathrm{x}+15.54$, looped: $\mathrm{y}=3.23 \mathrm{x}+13.43$.

the topped treatments in 1997, but not in 1995 or 1996 (Fig. 3). In the looped cane treatments $(5,10$, or 15 canes/hill), yield increased with cane density in all years (Fig. 3).

Machine harvest. In general, percentages of cull and drop fruit were not affected by cane density, training (Table 1), or production system (Table 3). Percentage of culls was greatest when the planting was young in 1995, averaging $10.7 \%$, vs. $8.7 \%$ and $3.6 \%$ in 1996 and 1997, respectively. Treatment effect on percentage of culls was statistically, but probably not biologically, significant in 1997 (Table 2). Percentage of culls was highest in the early years of the study, probably because the longer harvest interval adversely affected fruit quality.

Losses (percent drop) averaged $8.3 \%$ in 1995 , when the planting was young, $29.5 \%$ in
1996, and 16.2\% in 1997 (Table 2). Increasing harvest interval increased loss in 'Skeena' red raspberry in New Zealand (Kingston and O'Donoghue, 1987). In their study, percentages of total yield lost to the ground were $24 \%$, $30 \%$, and $32 \%$ for 2-, 4-, and 6-d harvest intervals, respectively. In our study, losses were only $8.3 \%$ when the planting was young in 1995, despite machine harvesting every $5 \mathrm{~d}$. Percent drop increased to $29.5 \%$ in 1996 , as plant vigor increased and the interval between harvests remained long (5 d). In 1997, drop was reduced to $16.2 \%$ by harvesting every 2 to $3 \mathrm{~d}$ (one of every three harvests was at a $3-\mathrm{d}$ interval), as is done commercially. The losses to machine harvest in the last year of this study were lower than those reported by others in the Pacific Northwest $[21 \%$ by Simpson et al. (1987) and 22\% by Martin and Nelson (1987)].
We found that $5.6 \%$ of the total yield loss in 1997 occurred between harvests; the remaining $10.6 \%$ of total yield fell to the ground during machine harvest. This is lower than the $14 \%$ reported by Kingston and O'Donoghue (1987) for both hand- and machine-harvested plots. Although machine type and operation may greatly impact machine harvest efficiency, production system and pruning and training appear to have little impact on losses to machine harvest.

Summary. Looping produced higher yields than topping, but slightly reduced fruit size and cold hardiness. Hedgerows were no more productive than were hill systems, and were more difficult to train. Neither pruning nor production system affected efficiency of machine harvest. Most loss of fruit occurred during harvest, and was greatest when the planting was mature and when time between harvests was prolonged.

\section{Literature Cited}

Braun, J.W. and J.K.L. Garth. 1984. Intercane yield compensation in the red raspberry. J. Amer. Soc. Hort. Sci. 109:526-530.

Buszard, D.J.I. 1986. The effect of management system on winter survival and yield of raspberries in Quebec. Acta Hort. 183:175-182.

Cormack, M.R. and P.D. Waister. 1976. Sources of yield loss in machine harvested raspberry crops. Acta Hort. 60:21-26.

Crandall, P.C., D.F. Allmendinger, J.D. Chamberlain, and K.A. Biderbost. 1974. Influence of cane number, diameter, irrigation, and carbohydrate reserves on the fruit number of red raspberries. J. Amer. Soc. Hort. Sci. 99:524-526.

Dale, A. 1989. Productivity in red raspberries. Hort. Rev. 11:185-228.

Kingston, C.M. and E.M. O'Donoghue. 1987. Red raspberry cv. Skeena: Influence of frequency of machine harvest on fruit yield and quality. N.Z. J. Expt. Agr. 15:81-85.

Martin, L.W. and E. Nelson. 1987. Mechanical harvest of red raspberry as affected by training system. HortScience 22:400-401.

Mason, D.T. 1981. A comparison of the hedgerow and stool systems of growing the red raspberry (Rubus idaeus L.) in relation to cane disease incidence and yield component compensation. Hort. Res. 21:149-158.

Morris, J.R. 1983. Influence of mechanical harvesting on quality of small fruits and grapes. HortScience 18:412-417.

SAS Institute. 1988. SAS/STAT user's guide. Release 6.03. SAS Inst., Cary, N.C.

Simpson, J.B., G.M.Hyde, H. Waelti, R.E. Thornton, C. MacConnell, and J.E. George. 1987. Mechanical raspberry harvester losses. Proc. Western Wash. Hort. Assoc. 77:133-135.

Wood, C.A., M.M. Anderson, and G.H. Freeman. 1961. Studies on the cultivation of raspberries. I. Effects of planting distances and of the winter tipping of canes. Hort. Res. 1:3-24. 